\title{
O PROFESSOR DE LÍNGUA PORTUGUESA E SUA HISTÓRIA COM A LEITURA
}

Patrícia Cardoso Batista ${ }^{*}$ Sheila Oliveira Lima ${ }^{* *}$

RESUMO: O enlace com a leitura depende, por vezes, do encontro com um mediador, que é aquele que faz a conexão entre livros e leitores. Em vista disso, este trabalho apresenta histórias de professoras de Língua Portuguesa com a leitura, objetivando uma reflexão sobre as relações que estabelecem em cada uma delas. É relevante entender como essas profissionais, que atualmente ocupam o papel de mediadoras na escola, constituíram sua própria relação com a leitura. Desse modo, questiona-se a existência de uma figura mediadora em suas experiências. Assim sendo, com base no recorte do corpus que compôs a dissertação de mestrado em Estudos da Linguagem da Universidade Estadual de Londrina, enfocaram-se os depoimentos coletados a partir de uma entrevista semiestruturada com docentes de Língua Portuguesa atuantes em duas escolas públicas do Paraná, embasadas na seguinte indagação: Como você se tornou um (a) leitor (a)? Trata-se de uma pesquisa de cunho qualitativo caracterizada como estudo de caso. Como resultados, observa-se que os percursos de formação leitora das professoras varia, pois ocorreram a partir de diferentes mediadores. Ademais, para algumas sua ocorrência se deu na infância, para outras na adolescência, ou mesmo somente após a entrada no curso de Letras. Portanto, percebe-se que não há idade para se tornar uma leitora, contudo, na história de algumas das participantes, os mediadores foram fundamentais para esse processo.

PALAVRAS-CHAVE: Formação de leitores; Mediação de leitura; Professores de Língua Portuguesa.

\footnotetext{
* Mestre em Estudos da Linguagem. Realiza pesquisa sobre ensino de leitura e formação do leitor literário na educação básica.

** Doutora em Linguagem e Educação pela Universidade de São Paulo (Usp). Professora do Departamento de Letras Vernáculas e Clássicas da Universidade de Londrina (Uel). É membro dos programas de pós-graduação PPGEL-UEL e Profletras-UEL. Mestre em Literatura Comparada e Teoria Literária. Realiza pesquisa sobre leitura, formação de leitores, ensino de leitura e formação de professores.
} 


\section{Introdução}

A aprendizagem da leitura, na maioria das vezes, acontece na escola, mas torná-la uma atividade recorrente e encantar-se por ela depende, por vezes, do encontro com alguém que já tenha descoberto isso para si. Logo, pode-se dizer que o momento em que se inicia a história pessoal com a leitura liga-se àquele em que se encontra com os mediadores, que são os responsáveis pela conexão dos leitores com os livros. Esses agentes contribuem na promoção da leitura, podendo ser, por exemplo, os pais, irmãos, amigos, professores, bibliotecários, entre outros.

O mediador é alguém que incentiva o ato de ler, dado que "O gosto pela leitura não pode surgir da simples proximidade material com os livros. Um conhecimento, um patrimônio cultural, uma biblioteca, podem se tornar letra morta se ninguém lhes der vida" (PETIT, 2009b, p. 154). Desse modo, torna-se crucial a importância de pessoas capazes de propagar sua paixão pelos livros, considerando que "A leitura é uma arte que se transmite, mais do que se ensina [...]" (PETIT, 2009a, p. 22).

Nessa perspectiva, destaca-se a importância da mediação da leitura na instituição escolar, pois “hoje, como em outras épocas, ainda que a 'escola' tenha todos os defeitos, sempre existe algum professor singular, capaz de iniciar os alunos em uma relação com os livros que não seja a do dever cultural, a da obrigação austera” (PETIT, 2009b, p. 158). Sendo assim, compreende-se que assumir o papel de mediador nesse ambiente implica o planejamento de estratégias de fomento à leitura, tais como a sugestão de livros, compartilhamento de experiências literárias e entusiasmo em relação a essa atividade. Ações estas que só são possíveis quando o profissional é um leitor.

Em vista disso, este trabalho apresenta histórias de professoras de Língua Portuguesa com a leitura, objetivando uma reflexão sobre as relações que estabelecem em cada uma delas. Essa investigação é relevante na medida em que proporciona aos educadores um retorno a sua própria formação leitora e, a partir disso, o autoquestionamento acerca do seu protagonismo na história de leitura de seus alunos bem como o reconhecimento da influência do docente que assume o papel de mediador na escola em que leciona. 
Trata-se de uma pesquisa de cunho qualitativo caracterizada como estudo de caso, com base no recorte do corpus que compôs a dissertação de mestrado em Estudos da Linguagem da Universidade Estadual de Londrina.

Neste artigo, são enfocados depoimentos coletados a partir de uma entrevista semiestruturada com docentes de Língua Portuguesa, atuantes em duas escolas públicas do Paraná, embasada na seguinte indagação: Como você se tornou um (a) leitor (a)?

Com base nesses relatos, observa-se que o percurso de formação leitora das professoras varia, pois ocorreu a partir de diferentes mediadores. Ademais, para algumas aconteceu na infância, para outras na adolescência, ou mesmo somente após a entrada no curso de Letras. Portanto, percebe-se que não há idade para se tornar uma leitora. Ressalte-se, contudo, que, na história de algumas das participantes, os mediadores foram fundamentais para esse processo.

O estudo baseou-se nas contribuições de teóricas de: Petit (2009), Machado (2016), Batista (1998), Lajolo (1998), entre outros.

\section{A leitura no Brasil: breve panorama histórico}

A história da leitura no Brasil inicia-se tardiamente, pois, segundo Zilberman e Lajolo (1996), as naus que trouxeram os portugueses não carregavam consigo os elementos necessários para a difusão da leitura e da literatura na nova terra. Para a literatura se constituir como prática social difundida era necessária a consolidação da "imprensa enquanto técnica, tipografias, editoras e livrarias enquanto atividade econômica, o jornal enquanto mídia, bibliotecas, gabinetes de leitura, sociedades literárias enquanto espaços culturais" (ZILBERMAN; LAJOLO, 1996, p. 97). Assim, os traços necessários para a formação e fortalecimento de uma sociedade leitora apareceram somente por volta de 1840. Tudo isso se deu graças à vinda da família real para o Brasil. Porém, tratou-se de um processo lento, sem abranger grandes camadas da população, pois tais recursos eram em poucas quantidades para atender a todos.

A história do leitor brasileiro começou devido à "expansão da imprensa, e desenvolveu-se devido à ampliação do mercado do livro, à difusão da escola, à alfabetização em 
massa das populações urbanas, à valorização da família e da privacidade doméstica e à emergência da ideia de lazer" (ZILBERMAN; LAJOLO, 1996, p. 14). A literatura mobilizou o mercado atraindo consumidores, transformando-se então em mercadoria. O livro tornou-se mais um objeto do capitalismo, com o intuito de obter cada vez mais lucros, caracterizando como uma das primeiras maneiras de entretenimento, mas que devido ao seu alto valor, era de difícil aquisição à maioria da população.

A educação no Brasil é marcada por seu início improvisado, instituída pelos jesuítas por motivos religiosos, que atendia a uma pequena parcela da população. O ensino da leitura e da escrita se iniciou na época da colonização. Nesse momento começou-se a ser ampliado para atender as pessoas de diferentes classes sociais, mas o privilégio de aprender permaneceu durante muito tempo somente à classe de poder. O Brasil necessitava de uma política educacional que prezasse pela instalação de uma rede escolar eficiente, porém, em primeiro lugar preocupou-se com as universidades, ficando em segundo plano o Ensino Básico.

Lajolo e Zilberman (1996) afirmam que, após a independência, pouco se fez pela educação. Essa época, caracteriza-se por escolas desaparelhadas, inexistência de livros, carência docente e precariedade em sua formação, improvisação, além de professores mal remunerados. Então, a formação de um público leitor se arrastou inconclusa e "rarefeita".

O livro didático merece destaque nesse percurso, já que é inegável que ele forma o leitor. Seu surgimento se deu pela necessidade de material para o ensino. Então, nasceu ao abrigo do Estado, juntamente com a imprensa, e por muito tempo se sujeitou a ele. O livro didático, foi nessa época matéria de literatura. Lajolo e Zilberman (1996) apresentam-no como "primo-rico das editoras", já que o governo encomenda-o em largas escalas, o que as enriquece, no entanto também é o primo-pobre, mas de ascendência nobre, pois faz parte de uma das condições de funcionamento da escola, visto que é o instrumento de trabalho do professor. Segundo as autoras, "por intermédio de sua trajetória de publicações 
e leituras, dá a entender que rumos seus governantes escolheram para a educação, desenvolvimento e capacitação intelectual e profissional dos habitantes de um país" (LAJOLO; ZILBERAMAN, 1996, p. 121).

Diante dessa trajetória, observa-se que os problemas que circundam a leitura na escola não são novos. Logo, muito ainda precisa ser feito para que as condições de sua produção melhorem. Atualmente, apesar da quantidade de escolas ter aumentado significativamente, não se prezou pela educação de boa qualidade. Em vista disso, grande parcela das escolas não possui boas estruturas físicas, suas salas de aulas são lotadas e as bibliotecas improvisadas.

Outro aspecto diz respeito à remuneração dos professores, que não é condizente com o que deles é exigido. Por isso, visando a sua sobrevivência trabalham em mais de um período, por vezes, em escolas diferentes. Somam-se a isso as poucas horas-atividade de que dispõem, cujo resultado será a falta de tempo e/ou disposição para se manterem atualizados, tanto teórico-metodologicamente quanto na leitura de livros literários. Para Silva (1998) os docentes tiveram seus direitos e iniciativas censurados através da restrição econômica.

Por fim, é também Silva (2003) quem expõe que a crise da leitura não é um fenômeno desta década ou mesmo deste século, na medida em que sempre houve, desde o período colonial, discriminação e marginalização no processo de formação de leitores. Desse modo, ao contrário do que diz o senso comum - que isso se deve à influência da televisão -, o autor afirma que tal problemática advém da participação desigual das classes sociais no acesso e na fruição dos conhecimentos veiculados pela escrita e das formas arbitrárias e fetichizadas de conceber e de se produzir a leitura. A leitura, de acordo com o teórico, é vista ainda diante do mundo capitalista como ócio descompromissado e desligado do trabalho produtivo.

\section{O professor de Língua Portuguesa}

Para Silva (1998) os docentes são peças fundamentais para mudar o atual cenário da leitura no meio escolar, porque, por mais que não possam mudar suas condições, por vezes, precárias de trabalho, eles podem tentar inovar e atualizar-se sobre outras metodologias existentes e colocá-las em prática em suas aulas. Em relação a isso, o autor ressalta 
que: "sem professores que leiam, que gostem de livros, que sintam prazer na leitura, muito dificilmente modificaremos a paisagem atual da leitura escolar" (SILVA, 1998, p. 22). Para ele, a leitura do professor precede a leitura do aluno.

Nesse sentido, os professores apresentam-se como protagonistas da promoção da leitura, principalmente, os que conduzem as disciplinas de Língua Portuguesa. Deste modo, pressupõe-se que, para ocupar esse papel, primeiramente, o docente tem que ser um leitor e ter uma boa relação com a leitura. Não que ele seja o único responsável por essa tarefa, mas devemos reconhecer que, para muitos educandos, sua única chance de ter um contato mais refinado com a leitura será por meio da escola, dado que nem todos possuem familiares leitores. Para Silva (1998) não se pode repassar às famílias uma função que elas não têm condições concretas de exercer.

Todavia, nem sempre é com essas condições que o aluno se depara na escola. Machado (2016) e Lajolo (2006) apontam que, com raras exceções, temos professores que não leem e nem mesmo vivem uma boa relação com o livro. Logo, isso tem refletido na relação com as leituras dos próprios alunos, dado que "Para transmitir o amor pela leitura, e acima de tudo pela leitura de obras literárias, é necessário que se tenha experimentado esse amor" (PETIT, 2009b, p. 161).

Nesse sentido, compreende-se que promover a leitura na escola implica dar o exemplo e passar a paixão pelos livros, porque não basta apenas ressaltar a importância dessa atividade. A esse respeito, Pennac (1993) critica a postura de muitos educadores que estabelecem a leitura como uma obrigação, pois questiona " $E$ se, em vez de exigir a leitura, o professor decidisse de repente partilhar sua própria felicidade de ler?” (PENNAC, 1993, p. $80)$.

Diante dessa realidade, percebe-se que a formação de professores tem falhado em algum momento, pois alguns têm passado pela universidade sem ter seu entusiasmo pela leitura despertado. Assim, não conseguem transmitir aos alunos aquilo que eles mesmo não desenvolveram. Essa realidade é exposta por Barbosa (2011 apudFORMIGA et al., 2015) ao afirmar que há docentes que saem do curso de Letras com questionamentos sobre o ensino 
de literatura que não foram solucionados em sua formação pedagógica. Desse modo, não descobriram o poder da leitura literária, restando-lhes acatar o que o livro didático traz:

Repetindo sem questionamento até a contemporaneidade o ensino da literatura inaugurado no século XIX, nossos cursos de Letras transformaram a literatura em história da literatura e a leitura dos textos literários em tarefa hermenêutica, restrita a uns poucos iluminados, afastando definitivamente o aluno da graduação e futuro professor de leitura dos textos literários, transformando-o em mero repetidor da "leitura correta" e apropriada dos críticos literários. Esse processo formou melhor bacharéis do que professores. (BARBOSA, 2011, p. 10 apud FORMIGA et al., 2015, p. 173)

Batista (1998), em sua pesquisa com professores de Língua Portuguesa, apresentou que estes são vistos pela imprensa, editoras de livros didáticos, pesquisas divulgadas sobre o assunto e outros envolvidos na formação inicial e continuada, como não leitores. Contudo, para ele, esta é uma questão problemática e complexa de ser abordada, dado que tem raízes sociológicas, as quais podem ser interpretadas a partir de diferentes perspectivas.

Diante disso, Batista (1998) expõe algumas hipóteses sobre o assunto a partir dos dados coletados em sua pesquisa com docentes. Nela, indica que a maioria dos professores de Língua Portuguesa corresponde à primeira geração da família a ter acesso a uma escolarização de longa duração. O autor ressalta que esses profissionais representam os resultados positivos da "democratização" do ensino brasileiro, pois atingiu categorias sociais até então excluídas.

Outro aspecto, apontado pelo autor refere-se ao incentivo da família na aquisição de competências em torno dos usos escolares da escrita. Logo, apresenta que esta é capaz de reconhecer a leitura como importante ao êxito escolar, contudo não a transmite devido a sua pequena apropriação do capital cultural.

Quanto a sua posição como leitores, o teórico apresentou que os docentes são leitores "escolares", dado que as suas leituras são realizadas visando o trabalho em sala de aula. Por isso são marcadas pela não-gratuidade e orientadas pela busca de conhecimentos. Ademais, a leitura do docente apresenta-se marcada por uma oscilação entre autores de 
prestígio e a literatura de massa, levando-o a indagar se os professores preferem livros afastados da cultura de prestígio.

A esse respeito, Batista (1998) expõe que a literatura mais escolarizada propõe ao leitor um rompimento com as formas tradicionais e solicita um universo de expectativas diferenciado. Nesse sentido, apesar de o professor reconhecer a legitimidade dessa literatura devido a sua escolarização, não significa que tenha desenvolvido as competências e disposições necessárias para fruí-las com desenvoltura.

Nesse cenário, para Batista (1998, p. 21, grifo do autor) “as relações e as disposições dos professores a respeito da leitura seriam antes parte de um processo de exclusão tardia ou de inclusão relativa". Daí que a mobilização pessoal e familiar para cursar o Ensino Superior resultou em um diploma e uma ocupação desvalorizados socialmente, pois a profissão docente apresenta-se sem prestígio social e, economicamente, o diploma tem baixo valor capital. Outro ponto é que a faculdade não foi suficiente para que criassem uma relação nãoescolar com a leitura, tendo proporcionado apenas o reconhecimento de objetos culturais legítimos. Por isso, reconhece-se que muitas variáveis têm influência no atual panorama da relação entre educador e leitura.

Entretanto, esse educador será, em boa parte das vezes, o responsável principal pela mediação entre livros e leitores em formação. Nesse sentido, parece-nos de fundamental importância refletir a respeito da função de mediador e compreender que esta deverá ser uma das atribuições dos educadores da escola básica.

Em Como um romance, Pennac (1993) aborda a história particular do leitor, mostrando-nos que esta, muitas vezes, se inicia na infância e termina na adolescência. Desse modo, o autor afirma que, quando a criança ainda não domina o código escrito, a leitura é mediada por um adulto, o qual lê em voz alta para ela. Logo, um encontro permeado pelo afeto entre aquele que lê e aquele que se dispõe a ouvir. Mas, ao tornar-se um adolescente espera-se que leia sozinho, podendo ser uma das possíveis causas da aversão a leitura.

Nessa mesma linha, Petit (2009b) afirma que a história com a leitura é marcada por encontros, seja esse na família ou em contextos mais amplos. Nessa perspectiva, a autora 
ressalta que o trajeto leitor é marcado, quase sempre, por um iniciador do livro, que é alguém que autoriza ou mesmo revela o desejo de ler. Por conseguinte, tem-se os outros mediadores, que são aqueles que acompanharam o leitor em diferentes momentos. A autora ressalta que o acompanhamento é essencial, porque o trajeto dos leitores é descontínuo e marcado por interrupções breves e curtas. Por isso, é preciso insistir, dado que, segundo Petit (2009b) não se entra na leitura como se abraça uma religião. Logo, o papel do mediador, para ela, é o de construir pontes entre os livros e os leitores.

Em relação aos agentes que ocupam o papel de mediadores, em sua pesquisa, a teórica francesa observou que muitos lembravam-se de um professor ou bibliotecário. Nessa perspectiva, Petit (2009b) ressalta que o amor pela leitura não nasce apenas da proximidade com os livros, mas a partir dos mediadores que transmitem sua paixão, curiosidade e desejo de ler. Sendo assim, ela enfatiza que esses agentes podem modificar um destino a partir da troca de conhecimentos e experiências literárias, que são oportunidades que muitos alunos não encontram no seio familiar. Em anuência, Pennac (1993, p. 84) aponta que: "Aquilo que lemos de mais belo deve-se, quase sempre, a uma pessoa querida."

Nesse sentido, ela ressalta que a escola, mesmo com seus impedimentos de diversas ordens, pode auxiliar na construção de boa relação dos alunos com a leitura. Mas, ela alerta para o fato de que nem todos são capazes de provocar movimentos acolhedores e transparentes que toquem os estudantes. Contudo, é possível que cada profissional se questione sobre sua própria relação com a língua e com a literatura.

\section{Análise de dados}

Neste tópico, apresentam-se os depoimentos de 10 professoras Língua Portuguesa, coletados em uma entrevista, partindo da seguinte pergunta: Como se tornou um (a) leitor (a)? Trata-se de uma pergunta aberta, na qual as profissionais tinham liberdade para aprofundar ou não, sua história com a leitura.

A professora 1 relata em seu depoimento que se tornou leitora tardiamente, reconhecendo as lacunas deixadas durante seu percurso escolar. 
Prof. 1: Eu me tornei uma leitora na faculdade, porque quando eu comecei a fazer Letras, eu não queria Letras, eu queria Direito. [...]. Então, como eu queria fazer Direito, eu li muitas obras para o vestibular. Fiz cursinho também, li muitas obras. Na faculdade a nossa professora de Literatura Brasileira e Portuguesa eram excelentes [...]. Então, eu peguei esse gosto com elas na faculdade, no Médio e no Fundamental, não.

Pesquisadora: O que faltou na sua formação escolar para tornarse uma leitora?

Prof. 1: Eu acho que incentivo da escola, né? E até mesmo dos próprios pais, porque os meus pais também não têm muito estudo, até a 8 a série no máximo. Então, para eles o importante é tirar notas, eu acho, né. Porque a leitura vai dos pais, quem tem um conhecimento maior. Para você incentivar teu filho você tem que ter aquele histórico também, porque se você não tiver um histórico de leitura, se você não gostar, você não vai incentivar o outro a fazer. Então, os meus pais não me incentivavam porque eles não tinham de onde tirar, não sabiam.

A participante 1 é enfática ao ressaltar que sua relação com a leitura se deu apenas ao adentrar o curso de Letras, momento em que se encontrou com mediadores que despertaram seu interesse pela atividade. Em vista disso, podemos afirmar que cabe também aos docentes dos cursos de formação de professores a tarefa de formar leitores, dado que temos que considerar que essa pode ser a realidade vivida por muitos estudantes do Ensino Superior em nosso país.

A história da Professora 1 coincide com a realidade vivida por muitos alunos, que têm pais não leitores e não encontram durante o período de escolarização ações voltadas à promoção da leitura. Ao justificar sua formação precária pela falta de "estudo" dos pais, a participante confirma os dados trazidos por Batista (1998), de que os professores de Língua Portuguesa são, em sua maioria, a primeira geração a dispor de um longo período de escolarização.

Observa-se que, apesar de a pesquisa não delimitar seu objetivo na identificação de informações sobre os familiares, isso surgiu nas falas de alguns participantes, provavelmente, devido à preocupação em justificar o tardio enlace com a leitura. 
Em sentido contrário, temos o relato da professora 2, que enfatiza a importância dos familiares para a criação de seu vínculo com a leitura:

Prof. 2. - Desde novinha eu sempre gostei muito de ler. Quando eu era mais jovem, uns 10 ou 12 anos, morava junto com a gente uma tia, que era professora. Por ela ser professora, ela tinha um acervo, então ela já nos apresentou a leitura, porque meu pai e minha mãe não eram leitores. Mas essa minha tia, que vivia com a gente, ela era bastante leitora, e tal, tinha vários livros de infanto-juvenil. Assim, eu me lembro que o primeiro livro que eu li foi o Açúcar Amargo e depois que eu li, eu praticamente devorei toda a série. Assim, eu gostei bastante. Desde então eu sempre li muito, ultimamente tenho lido mais livros técnicos. Mas sempre gostei muito de ler.

A participante 2 expõe que, desde a infância, desenvolveu uma boa relação com a leitura. Para isso, contou com a com participação da tia, dado que seus pais não eram leitores. A convivência com essa leitora foi crucial, o que confirma Machado (2016), para quem a constituição de uma boa relação com a leitura é aprendida com as pessoas a nossa volta, visto que ela é cultural, não natural ao homem. Outro aspecto interessante foi que o livro apresentado pela tia marcou sua trajetória, mostrando os impactos dos livros aos quais se tem acesso, sobretudo quando facilitado pela ação do mediador.

A explanação da professora 3 enfatiza a sua aversão à leitura na adolescência, tendo começado uma atividade leitora mais intensa somente após iniciar a docência, junto à necessidade de trabalhar com a literatura em sala de aula:

Prof. 3: Para falar a verdade? Na minha adolescência eu não gostava muito de ler. Mas, com o tempo eu fui obrigada a ler. Você tem que ler, né? Como você vai dar uma aula de literatura se você não conhece a obra? Comecei a ler depois da faculdade. Não tive quem incentivasse, minha mãe e meu pai são analfabetos, não tinham livros. Eu lia a série Vagalume, nem sei se existe mais, que eu ganhei uma coleção, eu lia e devorava. Eu ganhei porque escrevi para uma editora e eles me mandaram. [...] nem na faculdade eu estava ainda. O livro que marcou muito foi o Zezinho, o Dono da Porquinha Preta, que até hoje eu falo para a bibliotecária, alguém tem que ler, cadê esse livro? Não existe mais? Um livro que eu li obrigada na 
faculdade foi $\mathrm{O}$ pequeno príncipe, eu odiei. $\mathrm{Na}$ época eu não estava preparada para entender.

Pesquisadora: Mas e agora você gosta ou ainda não?

Prof. 3: Não, mas agora eu entendo, porque eu entrei na faculdade com 17 anos. O mundo nosso aqui, né? (Referindo-se à cidade em que vive). Não estava preparada para aquele tipo de leitura. Eu li [..], mas não entendi. Agora de tanto falar dele, eu falei vou ler de novo, entendi, mas não gostei.

Pesquisadora: E por que você gostou do livro o Zezinho?

Prof. 3: Eu gostei porque tinha muito a ver com a minha infância. [...]. Tinha uma ligação, eu me identifiquei muito com o livro.

Os dados apresentados pela professora 3 explicitam novamente que o docente de Língua Portuguesa, muitas vezes, não teve a convivência com pais leitores ou mesmo com materiais escritos em sua infância. Logo, esses resultados apresentam a importância de a escola assumir o papel de promotora da leitura e facilitadora do acesso às obras. Ressalta, ainda, a ocorrência da autoformação, na medida em que a professora 3 mostra-se preocupada em oferecer o melhor aos seus alunos de literatura. Nesse sentido, evidencia-se também a necessidade de programas de formação em serviço que possam amparar carências como as que são mencionadas no depoimento.

Ao concluir seu relato, a professora menciona livros com os quais se identificou bem como aqueles com os quais não teve afinidade alguma. É curioso notar que o livro lido na infância ainda ecoa no desejo da professora, uma vez que o busca na biblioteca de sua escola e se reporta a ele como objeto de valor. Por outro lado, trata o clássico como algo dispensável, sem importância para si e, talvez, também para seus alunos. Esses momentos em que a professora 3 evidencia sua relação de afeto com tais leituras também são indicativos relevantes a respeito de uma formação que, apesar da escolaridade, ainda se mantém precária, distante do entendimento dos argumentos que constituem o clássico. Nesse sentido, novamente tem-se um dado que coincide com a pesquisa de Batista (1998), ao apontar que o professor nem sempre adquire na escola a competência leitora necessária para a leitura de algumas obras literárias. Desse modo, ao adentrar a faculdade, depara-se com obras consideradas como legítimas, mas não consegue apropriar-se de condições de leitura para compreendê-las e apreciá-las. 
A professora 4 quando indagada se considera uma leitora, afirma que sim, e que começou a ler porque a sua profissão o exige:

Prof. 4: Devido a minha disciplina. Eu gosto, sempre que possível, eu estou lendo. Eu me tornei leitora através da minha profissão, de imediato eu achei que eu tinha por obrigação, quando me tornei professora de português. Para eu cobrar eu tinha que saber o que eu estava fazendo.

Pesquisadora: $\mathrm{Na}$ escola você não era uma leitora?

Prof. 4: Enquanto aluna na escola eu não era muito assídua, não. Só me tornei uma leitora através da profissão.

Pesquisadora: Você acha que faltou incentivo com a leitura?

Prof. 4: Pode ser que tenha faltado incentivo para a leitura na época, porque eu não sou tão nova. Os professores eram muitos, assim não tinha muito essa abertura para a leitura. Eu fui ler na faculdade por obrigação também. Então, enquanto estudante do Ensino Médio, não tinha essa cobrança nem essa abertura também da escola.

O depoimento dessa participante enfatiza um elemento muito importante que é o reconhecimento do seu papel social frente ao desafio da formação de leitores, entendendo que este implica ser uma leitora. Contudo, a partir do campo semântico utilizado em sua fala, é possível fazer algumas inferências. No início, a professora utiliza a palavra "cobrar", o que remete à leitura como mais uma atividade escolar obrigatória, à qual lhe foi atribuída. Ao final, essa concepção se justifica devido a sua própria experiência com a leitura, dado que apontou que, na graduação, realizava leitura devido às exigências estabelecidas, e que houve a ausência da escola nessa tarefa.

Nesse sentido, a leitura como atividade recorrente deu-se apenas no exercício da profissão, o que comprova a inexistência de uma relação com a leitura mais afetiva e subjetiva. A esse respeito Batista (1998) aponta que muitos professores realizam leituras visando apenas ao trabalho na escola, mostrando sua relação escolar com a leitura e orientada pela busca de novos saberes.

A professora 5 não explicita de fato como se deu sua história com a leitura, pois de início já enfatiza sua pouca leitura: 
Prof. 5: Leio muito, né? De acordo com o que dá tempo. Trabalhando em sala de aula não dá para ler muito os livros que eu gostaria de ler. Eu sempre gosto de estar lendo, estar interagindo com os meus filhos e com os alunos, eu leio bastante com eles, né? Aqui em sala de aula.

A justificativa para sua pouca leitura está enraizada na sua profissão, que ocupa boa parte do seu tempo, não sobrando momentos para dedicar-se às leituras de sua preferência. Deste modo, observamos novamente um dos dados destacados por Batista (1998), que diz respeito ao fato de que o professor de Língua Portuguesa é um leitor de obras escolares. Desse modo, compreende-se que a professora 5 lê em decorrência das atividades de sala de aula, mas, fora dela, não mantém uma relação afetiva com a leitura.

A professora 6, semelhante ao que ocorre com o depoimento da sua colega, parece ter pouco apreço por relatar sua relação com a leitura:

Prof. 6: Desde criança, foi lendo gibis. Foi através do meu irmão, ele gostava da Disney e eu também peguei. Comecei a me dedicar à leitura e gostei.

A participante vincula sua formação leitora a certa restrição material - os gibis - e menciona algo que tem se mostrado fundamental: a presença de um mediador, no caso, o irmão.

A professora 7 enfatiza o papel dos docentes na sua formação leitora, contudo não expõe nenhum em especial. Além do mais, enfatiza que, no período em que estava na adolescência, os recursos de entretenimento eram mais restritos em relação ao que se tem hoje.

Prof. 7: Através do incentivo dos meus professores.

Pesquisadora: Tem algum momento significativo na escola? Um professor que indicou um livro, algo assim?

Prof. 7: Não, especificamente não. Era uma forma que eu tinha de passar o tempo na época de adolescente, era a leitura.

Conforme se observa, a professora 7 , apesar de mencionar o papel mediador dos professores, não se refere a nenhum em especial nem a um evento mais específico em que a leitura tenha tomado um lugar de importância. Sendo assim, é possível considerar que, 
como no caso exposto, nem toda mediação assume maior relevância, não se fixando, assim, numa memória afetiva. Tal situação pode desvelar também o fato de tais mediações não serem tão expressivas na formação efetiva do leitor.

$\mathrm{Na}$ mesma linha, a professora 8 enfatiza o protagonismo dos educadores em sua formação, mas, ao contrário da participante 7 , recorda-se com exatidão o momento em que a leitura passou a ser uma atividade mais recorrente em sua vida, relatando sua participação em um projeto de leitura pertencente a sua escola, levando-a a escolher ser professora de Língua Portuguesa.

Prof. 8: Já faz tempo, assim, que eu comecei a gostar de ler. Acho que eu estava na $8^{a}$ série, mais o menos, aí eu comecei a ler bastante. Daí foi o que me incentivou a fazer Letras, porque comecei a gostar da literatura, essas coisas.

Pesquisadora: Foi algum professor?

Prof. 8: Foi a professora M., me ajudou bastante, participei do projeto dela.

Essa participante, portanto, tem a leitura como motivação para a escolha de sua profissão, não o contrário, isto é, como as demais, para quem a leitura é uma imposição do trabalho.

A professora 9, apresenta-se indecisa diante de sua postura como leitora:

Prof. 9: Eu gosto de ler, mas quase não tenho tempo de ler.

Pesquisadora: E na sua infância, adolescência?

Prof. 9: Gostava de ler.

Pesquisadora: Alguém te incentivou?

Prof. 9: Não, que eu me lembre, não. Foi uma coisa que eu sempre gostei mesmo.

Pesquisadora: E seus pais liam, professores?

Prof. 9: Não, que eu me lembre, não.

O discurso da participante 9 oscila entre ter a leitura desde "sempre" em sua vida, como algo que aprecia, mas para o que não dispõe de tempo para realizar. Para Pennac (1993) quando se coloca a falta de tempo como motivo para não ler é porque a vontade não está lá. A vida é um entrave permanente à leitura, pois todos, desde crianças a adultos têm seus afazeres. Por isso, pode-se dizer que o tempo para leitura é sempre roubado à 
obrigação de viver. Assim, o autor compara o tempo reservado para a leitura àquele para enamorar-se, para o qual, se dependesse do tempo ninguém se arriscaria. Portanto, concluise que "a leitura não depende da organização do tempo social, ela é, como o amor, uma maneira de ser" (PENNAC, 1993, p. 119). Logo, o valor dado à leitura parece ainda não ter sido constituído propriamente, o que a leva a não explorar elementos da sua história com a leitura, respondendo à questão de modo genérico.

Por fim, temos as alegações da professora 10:

Prof. 10: Então, eu acho que a leitura começa em casa. Eu acho que o despertar da minha leitura foi quando o meu pai contava histórias para mim, porque todos os dias eu pedia para que ele contasse histórias. Naquela época falava muito do Pedro Malazartes, e daí ele ia contando a história. Na verdade, no outro dia eu sentava no colo dele e falava: - repete para mim a história que você contou ontem. Então, era sempre as mesmas histórias. O meu pai, como era professor, me incentivou muito. Eu pedia livros de histórias para ele, queria ler gibi, e ele ia para I. e trazia livros de histórias infantis. Lembro muito bem do livro que ganhei $\mathrm{O}$ patinho feio. Então, eu acho que tudo começou em casa com o meu pai. Daí eu comecei a ler aqueles livros, Sabrina, Júlia, como era menina gostava muito daquele tipo de leitura. Então, a partir eu descobri que nos livros tinham várias histórias interessantes. Sempre falo para minhas alunas: - podem ler Júlia, pode ler Sabrina, porque foi aí que eu despertei para a leitura. Foi por isso.

Pesquisadora: E depois você decidiu fazer Letras por isso também?

Prof. 10: Daí o que aconteceu, com essas leituras que eu tive na infância e desses livros, pude ver que eu conseguia entender um pouco mais de Português, assim comecei a gostar mais da literatura e aí fui mais para essa opção. Eu queria ser professora, mas do que? - Bom, vou ser de Literatura, porque eu gosto muito de ler, gosto muito de Língua Portuguesa. Enfim, daí acho que foi despertando.

A história com a leitura dessa docente teve início por meio da literatura oral, sendo marcada pelo afeto entre pai e filha, que compartilhavam narrativas. Mas essa participante também dispunha do contato com material impresso, dado que ressalta que ganhava livros na infância. Assim, apenas essa participante citou que o pai era leitor, e ainda formado em um curso de Ensino Superior. 


\section{Conclusão}

Como resultados, observou-se que poucas professoras se tornaram leitoras na infância, dado que explicitaram que vêm de famílias onde não havia leitores ou mesmo eram a primeira geração a ter acesso a um longo período de escolarização. Logo, esse dado evidencia que não se pode deixar somente a família encarregada dessa função, cabendo, portanto, a outras instituições sociais, tal como a escola, ocuparem esse papel.

Contudo, nos casos analisados, mesmo o ambiente escolar deixou lacunas, porque algumas profissionais explicitaram que passaram longos períodos da escolarização sem que tivessem criado uma boa relação com a leitura ou que a escola as tenha amparado nesse sentido.

Quanto aos responsáveis por tornarem-se leitoras, as respostas basicamente apresentaram duas instituições: a escola (básica, superior ou na condição de professoras) e a família. Esmiuçando os dados, percebe-se que a maior parcela das docentes não atribuiu a nenhuma pessoa em específico a sua formação leitora, pois esta se deu a partir do papel social e profissional que ocupa. Aquelas que não citaram uma pessoa como mediadora, mencionaram uma instituição responsável por sua leitura. Os caminhos percorridos por cada uma na constituição como leitora mostraram-se diferentes em alguns pontos e semelhantes em outros. Mas ainda temos professoras que em seu depoimento passaram a impressão de que veem a leitura apenas como obrigação, evidenciando que ainda não têm vínculo efetivo e afetivo com tal prática letrada.

A leitura envolve uma relação também afetiva, que, muitas vezes, é deflagrada a partir da mediação realizada por alguém que se coloca como elo entre leitor e texto. Em vista disso, observa-se que lacunas se abrem tanto no seio da família quanto na educação básica, havendo a necessidade de a escola e, posteriormente, a faculdade supri-las.

Desse modo, nota-se a necessidade de a formação de professores cativar seus estudantes para a leitura, pois a relação com essa atividade interfere diretamente na futura prática em sala de aula. Ao levar os licenciandos a refletir sobre seu percurso de formação 
leitora, é possível conscientizá-los da importância de se tornarem efetivos mediadores, atuantes no processo de enlace entre o jovem leitor e a literatura.

Nesse sentido, este trabalho ressalta que a escola, apesar de suas falhas, é o local propício para a formação de leitores, já que as crianças e jovens a frequentam por um longo período. Mas, cabe também à universidade não se abster de tal tarefa. Por isso, trata-se de um desafio que abrange todo o segmento educacional.

\section{EL PROFESOR DE LENGUA PORTUGUESA Y SU HISTORIA CON LA LECTURA}

RESUMEN: El vínculo con la lectura depende, a veces, del encuentro con un mediador, que es aquel que hace la conexión entre libros y lectores. En vista de esto, este trabajo presenta historias de profesoras de Lengua Portuguesa con la lectura, con el objetivo de una reflexión sobre las relaciones que establecen en cada una de ellas. Es relevante entender cómo estas profesionales, que actualmente ocupan el papel de mediadoras en la escuela, constituyeron su propia relación con la lectura. De este modo se cuestiona la existencia de una figura mediadora en sus experiencias. Así pues, sobre la base del recorte del corpus que compuso la tesis de máster en Estudios del Lenguaje de la Universidad Estatal de Londrina, se enfocaron los testimonios recogidos a partir de una entrevista semiestructurada con docentes de Lengua Portuguesa actuantes en dos escuelas públicas del Paraná, basadas en la siguiente indagación: ¿Cómo te convertiste en un(a) lector(a)? Se trata de una investigación de carácter cualitativo caracterizada como estudio de caso. Como resultados, se observa que los itinerarios de formación lectora de las profesoras varían, pues ocurrieron a partir de diferentes mediadores. Además, para algunos su ocurrencia se dio en la infancia, para otros en la adolescencia, o incluso sólo después de la entrada en el curso de Letras. Por lo tanto, se percibe que no hay edad para convertirse en lectora, pero en la historia de algunas de las participantes, los mediadores fueron fundamentales para ese proceso.

PALABRAS CLAVE: Formación de lectores; Mediación de lectura; Profesores de Lengua Portuguesa.

\section{REFERÊNCIAS}

FORMIGA, Girlene M.; INÁCIO, Francilda A.; BARBOSA, Socorro de Fátima P. Literatura, escola e formação literária: entre práticas e descaminhos. Revista Principia. João Pessoa, n. 28, p. 169-177, dez. 2015. Disponível em: file://C:/Users/User/Downloads/3891228-1-PB\%20(1).pdf. Acesso em: 13 maio 2019.

BATISTA, Antônio Augusto Gomes. A leitura incerta: a relação de professores (as) de Português com a leitura. Educação em Revista (UFMG), Belo Horizonte, n. 27, p. 01-26, 1998. LAJOLO, Marisa. Do mundo da leitura para a leitura do mundo. 6. ed. São Paulo: Ática, 2006. LAJOLO, Marisa; ZILBERMAN, Regina. A formação da leitura no Brasil. São Paulo: Ática, 1996. 
MACHADO, Ana Maria. Ponto de fuga: conversas sobre livros. São Paulo: Companhia das Letras, 2016.

PENNAC, Daniel. Como um romance. Tradução de Leny Werneck. Rio de Janeiro: Rocco, 1993.

PETIT, Michèle. $A$ arte de ler: ou como resistir à adversidade. Tradução de Arthur Bueno e Camila Boldrini. São Paulo: Editora 34, 2009a.

PETIT, Michèle. Os jovens e a leitura: uma nova perspectiva. Tradução de Celina Olga de Souza. São Paulo: Editora 34, 2009b.

SILVA, Ezequiel T. Elementos de pedagogia da leitura. 3. ed. São Paulo: Martins Fontes, 1998 SILVA, Ezequiel T. Leitura na escola e na biblioteca. 8.ed. Campinas: Papirus, 2003.

Recebido em: 31/05/2019.

Aprovado em: 30/07/2019. 